Pflügers Arch (1992) 420:87-93

\title{
High-resolution measurements of gap-junctional conductance during perfusion with anti-connexin antibodies in pairs of cultured mammalian cells
}

\author{
D. Paschke, R. Eckert, and D. F. Hülser \\ Abt. Biophysik, Biologisches Institut, Universität Stuttgart, Pfaffenwaldring 57, W-7000 Stuttgart 80, Federal Republic of Germany
}

Received January 31, 1991/Received after revision August 22, 1991/Accepted September 17, 1991

\begin{abstract}
Antibodies against the main proteins in hepatic gap junctions - connexin-26 and connexin-32 - have been used in conjunction with high-resolution patchclamp techniques to investigate whether a relation exists between connexin type and conductance of single gapjunctional channels. Two different cell lines, BRL cells, derived from rat liver, and FL cells a human amniotic cell line exhibited the same single-channel conductances in double whole-cell recordings, but reacted differently upon dialysis with antibodies. Preliminary results indicate that both cell lines express mainly connexin-43. Thus, in spite of the inhibitory action of anti-cx 26 and anti-cx32 antibodies observed, the data question the reliability of these antibodies for the functional characterization of gap-junction proteins in electrophysiological experiments.
\end{abstract}

Key words: Intercellular communication - Gap junctions - Connexin proteins - Internal perfusion Double whole-cell recording - BRL cells - FL cells

\section{Introduction}

Gap-junction channels mediate direct intercellular communication in many developing and differentiated organs and tissues (for review see monographs edited by DeMello [4]; and Robards et al. [16]). The structure and function of these channels can be studied with cultured cells, where ionic and metabolic coupling can be measured under controlled conditions. The structure of gap junction channels has been investigated with biochemical and biophysical methods, and the results indicate that a hemichannel (connexon) consists of six protein subunits [23], the so-called connexins [2]. A fully operational gapjunction channel is formed when two connexons of adjacent cells are linked together. Molecular analyses and determination of amino acid sequences revealed the exis-

Offprint requests to: D. F. Hülser tence of several types of connexin proteins, which all contain four putative membrane-spanning domains, forming two outer and one inner loops with both amino and carboxyl terminus at the cytoplasmic side, as was first described for the connexin protein cx32 [26].

In liver mainly two proteins, ex26 and cx32, were isolated from gap junctions [25], whereas heart cells are characterized by another type, connexin cx43 [1], which is also present in some cultured fibroblast lines [25]. Both cx26 and cx43 share sequence homology with the "reference protein" cx32 and are considered as members of a common connexin gene family [25]. However, in liver and hearts as well as in many other cells a $16-\mathrm{kDa}$ protein was co-isolated from gap junctions $[6,7]$ that has no homology to $\mathrm{cx} 32$ and is, therefore, not termed "connexin".

Antibodies raised against connexins have mainly been used as biochemical probes to identify gap-junction proteins in Western blots of membrane proteins from different tissues (for review see [25]). Some of these antibodies have also been used for the investigation of connexin functions, since they block junctional transfer of fluorescent dyes when injected into a cell $[8,24]$. Antibodies directed against $\mathrm{cx} 32$ block dye spreading in the rat liver cell line BRL and the human amniotic cell line FL, as has been shown by Brümmer [3].

Using the double whole-cell recording technique [11], we were able to record and analyse currents through single gap-junction channels between BRL as well as FL cell pairs. The wide tip diameter of patch pipettes permits an exchange of pipette medium against cytoplasmic compounds by diffusion [10,15], we, therefore, also dialysed the cells with antibodies directed against connexins while simultaneously recording their junctional conductance. From these experiments we expected some evidence of whether gap-junction channels are assembled from a single connexin type and whether such homomeric channels would exhibit unitary conductances that are characteristic for the different connexins, as has been proposed by Eghbali et al. [5] or Rook et al. [18]. The antibody reaction, however, appeared to be rather non-specific and 
did not allow a correlation between connexin type and the conductance levels of gap-junction channels.

\section{Materials and methods}

Cell culture. Two permanently growing cell lines have been used for our investigations: BRL (ATCC CRL1442) epithelioid rat liver cells, and FL (ATCC CCL62) epithelioid cells derived from human amniotic membrane. Both cell lines were cultivated as monolayers in Dulbecco's modified Eagle's medium (Biochrom KG, Berlin, FRG) supplemented with $3.7 \mathrm{~g} / 1 \mathrm{NaHCO}_{3}, 100 \mathrm{mg} / 1$ streptomycin sulphate, $150 \mathrm{mg} / \mathrm{l}$ penicillin $\mathrm{G}$, and $10 \%$ fetal calf serum at $\mathrm{pH} 7.4$ and $37^{\circ} \mathrm{C}$ in a humidified incubator with an $8 \% \mathrm{CO}_{2} /$ air mixture. For the preparation of cell pairs, the culture medium was decanted and the cells were rinsed with phosphate-buffered saline (PBS) to remove serum components. After addition of $1 \mathrm{ml}$ ice-cold trypsin $(0.25 \%$ in PBS, calcium- and magnesium-free) to the dish, the cells were incubated for about $0.5-1 \mathrm{~min}$ at $37^{\circ} \mathrm{C}$. Trypsinization was stopped by adding $2.5 \mathrm{ml}$ culture medium containing $10 \%$ serum and the cells were dissociated by gentle agitation with a pasteur pipette. This suspension was allowed to settle on glass cover slips (14 mm diameter). After $10 \mathrm{~min}$ at $37^{\circ} \mathrm{C}$, when about $80 \%$ of the cells had attached to the glass, a cover slip was removed from the culture dish, rinsed with PBS or extracellular saline $(130 \mathrm{mM} \mathrm{NaCl}$, $5.4 \mathrm{mM} \mathrm{KCl}, 1.4 \mathrm{mM} \mathrm{CaCl}, 0.5 \mathrm{mM} \mathrm{MgCl}_{2}, 10 \mathrm{mM}$ Hepes/ $\mathrm{NaOH}, \mathrm{pH} 7.3)$ and transferred into an experimental chamber containing extracellular saline as bath medium.

Measurement of ionic coupling, Gap-junctional coupling was measured with the double whole-cell patch-clamp procedure [11]. Pipettes were pulled from soft glass microcapillaries (CeeBee hematocrit, Chr. Bardram, Svendborg, Denmark) in two steps to a final resistance of $2-5 \mathrm{M} \Omega$ when filled with intracellular solutions. The pipettes were fire-polished and used without Sylgard coating. Pipettes were back-filled with physiological intracellular saline (140 mM KCl, $5 \mathrm{mM}$ EGTA/KOH, $10 \mathrm{mM}$ Hepes/KOH, pH 7.3, $\mathrm{pCa}>8$ [11]). To reduce the rundown of transjunctional conductance during antibody perfusion we adopted the procedure of Somogyi and Kolb [21] and added ATP and dibutyryl-cAMP to the saline $(140 \mathrm{mM} \mathrm{KCl}, 5 \mathrm{mM}$ ATP, $1 \mathrm{mM}$ dibutyryl-cAMP, $5 \mathrm{mM}$ EGTA/KOH, $10 \mathrm{mM}$ Hepes/KOH). All solutions were filtered through a $0.2-\mu \mathrm{m}$ membrane filter to prevent clogging. For current recordings two List EPC-7 patch-clamp amplifiers (List Electronics, Darmstadt, FRG) were used. Pipettes were placed into holders at the amplifier headstages and a positive pressure was applied to the pipette interior resulting in an efflux of pipette contents. Immediately after the dual whole-cell mode was established, the time count of the experiment was started $(t=0)$ and the initial conductance $g\left(t_{0}\right)$ was used as a $100 \%$ reference to characterize the decay of junctional coupling. During the experiment the cells were observed through a Leitz Fluovert inverted microscope supplied with phasecontrast and epifluorescence equipment.

Junctional coupling was tested throughout the experimental time course by injecting $0.02-\mathrm{Hz}$ square pulses of $10 \mathrm{mV}$ or $25 \mathrm{mV}$ into one cell and measuring the resulting current in the other cell. The current recordings from both cells were monitored with a twochannel digital storage oscilloscope (Nicollett 3091, Nicollett Instrumentation Company, Madison, Wis.). From these data the junctional conductance was determined according to the formula given by Rook et al. [17]. The time course of uncoupling was determined by scaling the conductance at each time point $g(t)$ by the initial value $g\left(t_{0}\right)$. These normalized conductances of several experiments were averaged and time constants were calculated from the averaged records by least-squares fitting to single-exponential decay functions using standard techniques [14]. Current fluctuations through single gap-junction channels were recorded in voltage-clamped cell pairs as described by Neyton and Trautmann [11]. The data were lowpass-filtered at $0.25 \mathrm{kHz}$ and stored on video tape, from which stretches of $1-10$ min were played back and sampled to the hard disk of an IBM-AT microcomputer for further processing. For both mirrored current traces of a single-channel record, amplitude distributions were calculated [20], from which channel current steps can be derived. For data analysis we used programs that were developed in our laboratory following standard techniques for single-channel analysis $[12,19]$ and tailored to suit the needs of double whole-cell measurements. These programs were originally adopted from McCann et al. [12] and run within ASYST, a data acquisition and analysis package for the IBM PC. Current/voltage diagrams were constructed using the data from amplitude histograms and direct inspection of the records of several experiments (two to five experiments) at different transjunctional voltages. Mean channel conductances were derived from the slope of the current/ voltage relation determined by linear regression analysis.

Antibody injection. Two different antibodies were used: an affinitypurified polyclonal antibody directed against $\mathrm{cx} 26$ [22] and a monoclonal anti-cx32 antibody [9] with the respective preimmune serum for control experiments. All antibodies were diluted to a concentration of $0.4 \mathrm{mg} / \mathrm{ml}$ in pipette saline. For antibody experiments pipettes were filled by dipping their tips into a droplet on intracellular saline and applying suction at its back end, so that less than $0.5 \mu \mathrm{l}$ liquid was drawn into the tip. Then $0.5 \mu 1$ antibody solution was overlayed from the rear end with a Hamilton syringe and, finally, the pipette was back-filled completely with the respective intracellular saline. This procedure was necessary because otherwise binding of antibody to the pipette tip will interfere with seal formation. To determine the time interval for the antibody diffusion into the cell, we used fluorescein-isothiocyanate(-FITC)-labelled IgG [goat anti-(rat IgG), Sigma F 6258, Sigma, St. Louis, USA] and monitored the spread of FITC fluorescence into the cell.

Measurement of dye transfer. For dye-spreading experiments about $1 \mu \mathrm{l}$ Lucifer yellow was overlayed instead of antibody solution (4\% Lucifer yellow $\mathrm{CH}$, Sigma, in $1 \mathrm{M} \mathrm{LiCl}$ solution). The dye was allowed to diffuse into the cell without any additional driving force (e,g. pressure injection or iontophoretic transfer). For fluorescence experiments the microscope was equipped with appropriate filter sets (N2 and E3 filter cartridges). All experiments were carried out at room temperature.

\section{Results}

\section{Spontaneous loss of gap-junctional conductance}

With our preparation, a sufficient number of isolated cell pairs was obtained, which were adherent to but not yet spreading on the glass surface. These rounded cells were ideally suited for whole-cell measurements because of their increased input and cell-to-cell resistance and improved noise characteristics as compared to monolayer cells. The typical non-junctional membrane resistance (input resistance) of a single cell was $4.1 \pm 2.6 \mathrm{G} \Omega(n=$ 11) for BRL and $3.6 \pm 3.0 \mathrm{G} \Omega(n=10)$ for FL cells (mean \pm standard deviation). Initially, after establishing the double whole-cell configuration, most of the FL and BRL cell pairs had cell-to-cell conductances $g\left(t_{0}\right)$ between $18 \mathrm{nS}$ and $80 \mathrm{nS}$ (corresponding to cell-to-cell resistances of $55.5 \mathrm{M} \Omega$ and $1.25 \mathrm{M} \Omega$ respectively). Whole-cell recording always leads to a dilution of the cytosol with pipette medium (cell dialysis, $[10,15]$ ), and this often results in unwanted side-effects such as "run down" of channel kinetics. Under these experimental conditions (electrodes filled with intracellular saline only) gap-junctional conductance spontaneously decreased during the experiment until finally the cells became electrically un- 


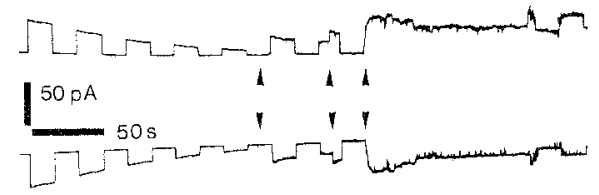

Fig. 1. Current records during spontaneous gap-junctional uncoupling in BRL cell pairs. The upper trace represents the cell, which was clamped to $-15 \mathrm{mV}$ and where square pulses of $0.02 \mathrm{~Hz}$ and $10 \mathrm{mV}$ amplitude were applied to the pipette. The lower trace represents the neighbouring cell, which was held at a constant voltage of $-5 \mathrm{mV}$. The arrows indicate gain switching at the amplifier until finally single-channel fluctuations were resolved. Scale valid until first arrow
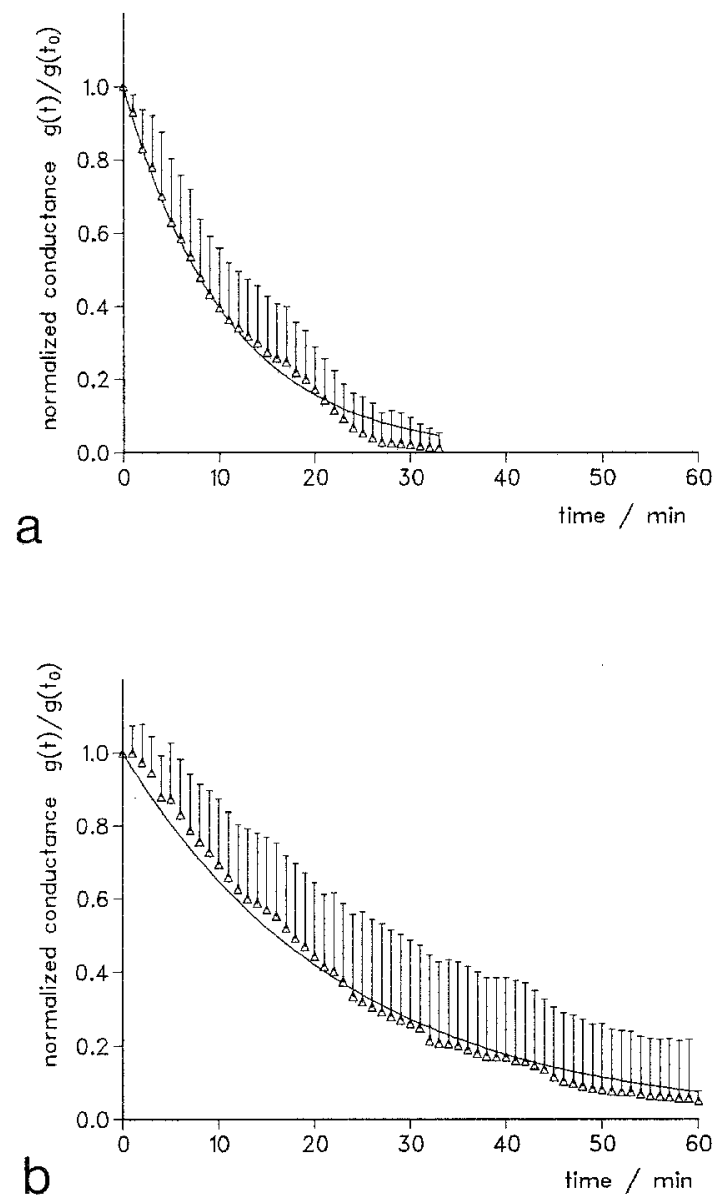

Fig. 2. Time course of the decrease in junctional conductance during spontaneous uncoupling in (a) BRL and (b) FL cell pairs. Junctional conductance $g(t)$ was normalized to its initial value $g\left(t_{0}\right)$ and averaged over 25 experiments for BRL and 17 experiments for FL cells. $\triangle$, Ensemble mean plus standard deviation; - _..., fitted exponential decay curve (see also Table 1)

coupled as demonstrated in Fig. 1 for BRL cells. The time course of these uncoupling processes is best fitted by exponential decay functions as is shown in Fig. 2, where the junctional conductance $g(t)$ was normalized to $g\left(t_{0}\right)$ and averaged over several experiments. The fitted time constants for this "spontaneous uncoupling" were $11 \min (n=25)$ for BRL and $23 \min (n=17)$ for FL cells as determined by least-squares estimation.

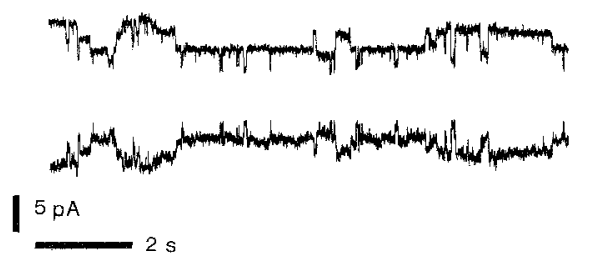

Fig. 3. Curent fluctuations through single gap-junction channels at the end of spontaneous uncoupling in a BRL cell pair. Upper trace: current recording from the cell clamped to $-5 \mathrm{mV}$; lower trace: current recording from the cell clamped to $-35 \mathrm{mV}$. Transcellular voltage was $30 \mathrm{mV}$, both traces were low-pass-filtered at $0.25 \mathrm{kHz}$

About $30-40$ min after starting the experiment, when the junctional conductance had decreased to about $200 \mathrm{pS}$, discrete current fluctuations could be resolved in both cell lines (Fig. 1), which are attributed to the opening and closing of single gap-junction channels. They appear as mirrored deflections in the current records from both cells (Fig. 3). These current fluctuations were usually observed for several minutes until the cells finally completely uncoupled. Within the limit of resolution, both BRL and FL cells revealed identical patterns of single channel conductances. From the current/voltage relations of the main current steps, single-channel conductances of about $60 \mathrm{pS}$ and $90 \mathrm{pS}$ have been computed from the records (Figs. 4, 5).

\section{Antibody perfusion during spontaneous uncoupling}

To test whether these two current steps originate from different types of connexons, we perfused the cells with antibodies directed against cx 26 and cx32 proteins and measured the rate of uncoupling under these conditions. For this purpose, the antibodies were added to the patch pipette solution and allowed to diffuse into the cell. To verify antibody perfusion and to estimate the diffusion rate of antibody from the patch pipette into a cell, we used FITC-labelled IgG as a probe and monitored the spread of fluorescence from the pipette in a separate set of experiments $(n=19)$. To avoid bleaching, fluorescence in the cytoplasm of the perfused cells was tested at about 3-min intervals and appeared 6-9 min after establishing the whole-cell mode, indicating the presence of antibody inside the cells. This time varies mainly with the volume of antibody-free saline remaining in the pipette tip and is, therefore, longer than the time constants of 0.5 $1.5 \mathrm{~min}$, which may be calculated after the data given by Pusch and Neher [15] for IgG. In any case, this is shorter than the observed time constants of antibody-induced uncoupling. The results of experiments with preimmune serum in BRL cells and with antibody in BRL and FL cells are summarized in Table 1 . The variability within one measurement increased with the presence of antibody in the pipette and the statistical ensemble variance increased with regard to control experiments since - because of the limited amount of antibody - only a few successful measurements could be performed (usually $4-$ 10 versus $17-25$ control measurements). 

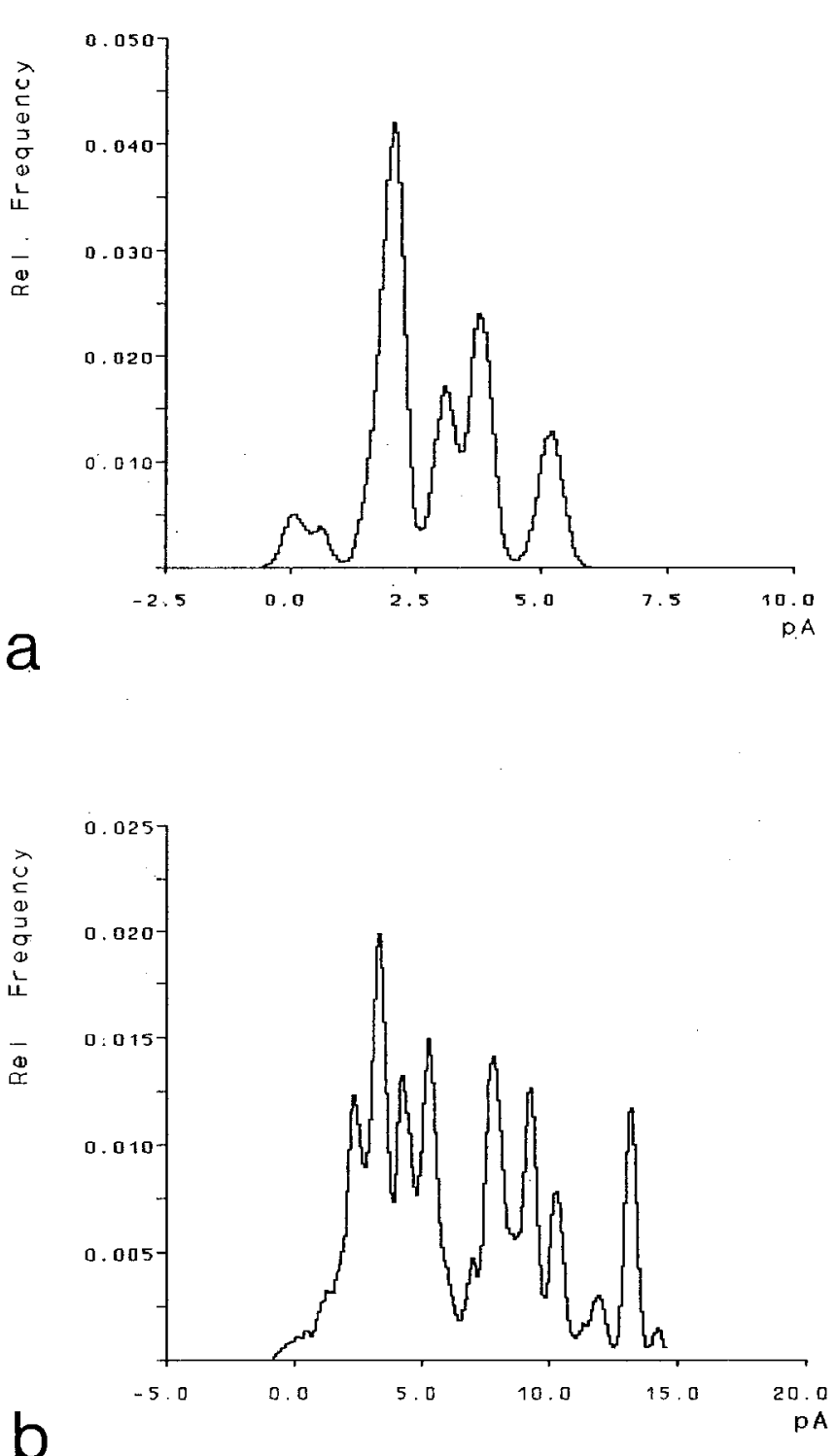

Fig. 4. Amplitude histograms from current records of (a) BRL and (b) FL cell pairs after spontaneous uncoupling. Both records were low-pass-filtered at $0.25 \mathrm{kHz}$; transjunctional voltage was $20 \mathrm{mV}$. Histograms correspond to data sets of (a) $70 \mathrm{~s}$ (b) $45 \mathrm{~s}$ sampled at a rate of 700 samples/s. The histograms were calculated using a bin width of $0.03 \mathrm{pA} /$ bin and smoothed by a median filter for display. Peaks in a were detected at $0.6 \mathrm{pA}(\equiv 30 \mathrm{pS}$, not included in Fig. 5), $1.8 \mathrm{pA}(\equiv 90 \mathrm{pS}), 3 \mathrm{pA}(\Delta I=1.2 \mathrm{pA} \equiv 60 \mathrm{pS})$ etc. In b similar current peaks can be seen

\section{Antibody perfusion during retardation of uncoupling}

The high rate of "normal" uncoupling can be overcome by applying the procedure described by Somogyi and Kolb [21], who stabilized junctional conductance by adding $5 \mathrm{mM}$ ATP and $1 \mathrm{mM}$ dibutyryl-cAMP to the pipette medium. This supplemented intracellular saline, slowed down electrical uncoupling for a sufficiently long recording period, increasing the time constants from $11 \mathrm{~min}$ to $104 \mathrm{~min}$ for BRL and from $23 \mathrm{~min}$ to $67 \mathrm{~min}$ for FL cells (see Fig. 6a and b, and Table 1).

Repeating the antibody-perfusion experiments with ATP/dibutyryl-cAMP-supplemented intracellular saline

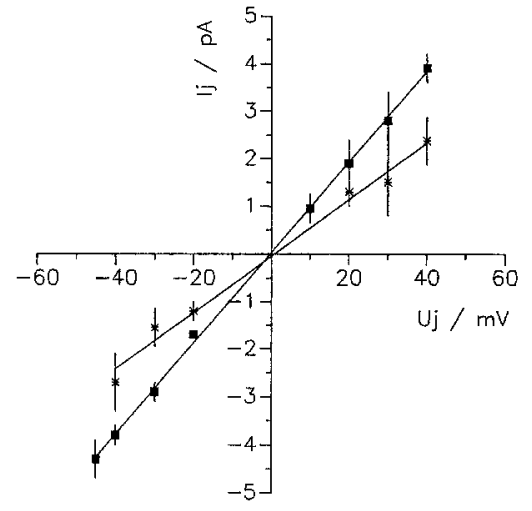

a

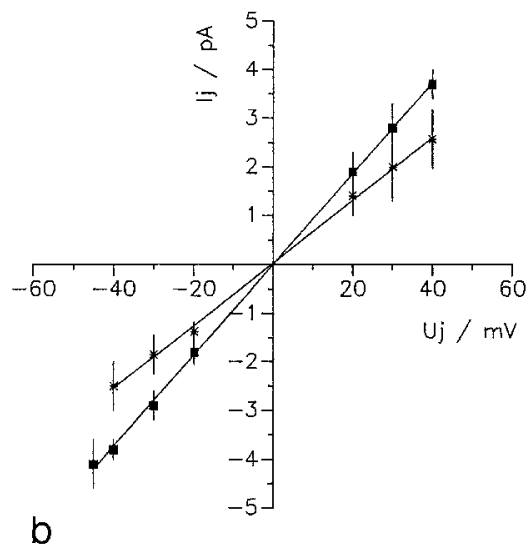

Fig. 5. Current/voltage relation of the two main current steps observed in single-channel recording from gap-junctional channels in (a) BRL and (b) FL cell pairs. The slopes of the curves correspond to conductances (mean \pm standard deviation) of $60 \pm 3.5 \mathrm{pS}\left({ }^{*}\right)$ and $95 \pm 8.5 \mathrm{pS}(\boldsymbol{\square})$ for $\mathrm{BRL}$ and of $63 \pm 4 \mathrm{pS}\left({ }^{*}\right)$ and $91 \pm 6 \mathrm{pS}$ (ם) for FL cells respectively. In individual experiments larger and smaller conductance steps were distinguished and both groups were averaged irrespective of the absolute conductance levels

clearly revealed a junctional blocking capacity of the antibodies. BRL cells were affected by both anti-cx 26 and anti-cx32 antibodies (Fig. 7a), whereas the effect of preimmune serum was not different from control measurements (Fig. 8). FL cells showed an accelerated uncoupling only for the cx26 antibodies (Fig. 7b). The results of these experiments are also summarized in Table 1. The question whether the antibodies altered the single-channel properties is difficult to answer since the antibody treatment resulted in a considerable perturbation of the membrane properties. Usually, cell input resistances decreased and noise increased so that - except for one experiment (Fig. 9) - single-channel events could no longer be resolved. This experiment, however, did not show any significant differences in single-channel behaviour, when compared with an experiment with spontaneous uncoupling (Fig. 3).

To illustrate the uncoupling effect of antibody by inhibition of dye spreading, we performed experiments with three attached cells using the same experimental set-up. Figure 10 shows one of those experiments with BRL cells, where cell 1 was perfused with anti-cx32 until total electri- 
Table 1. Time constants of junctional uncoupling during perfusion with antibody in intracellular saline (IS: spontaneous) and IS supplemented with ATP + dibutyryl-cAMP (IS ATP $_{\text {: stabilized) }}$

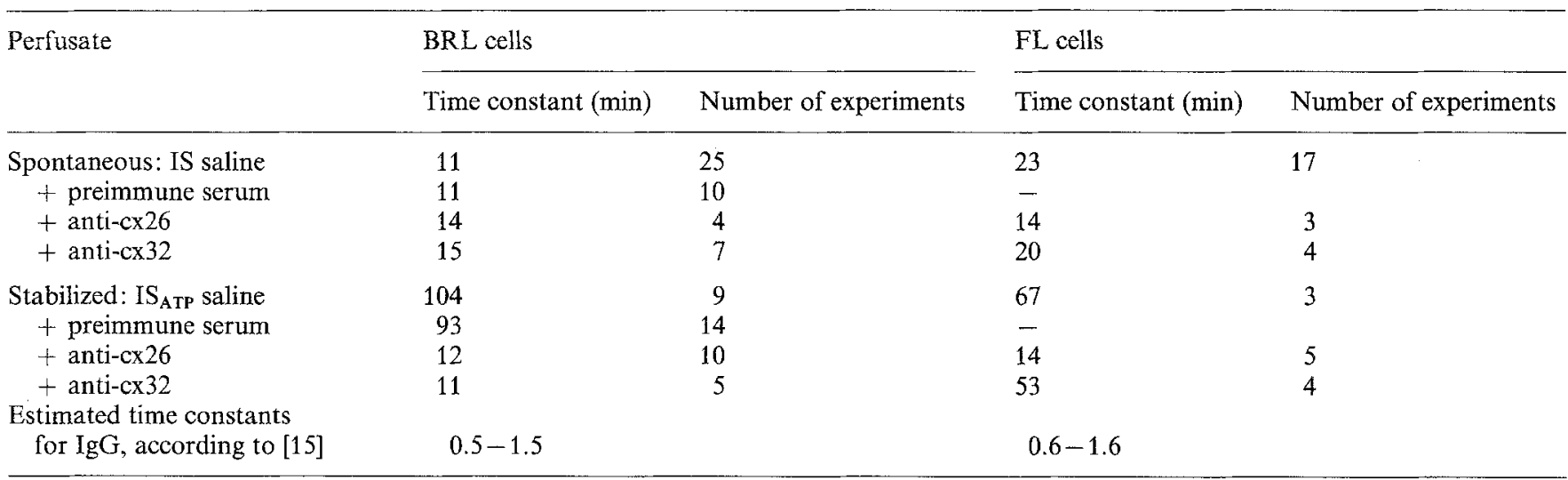
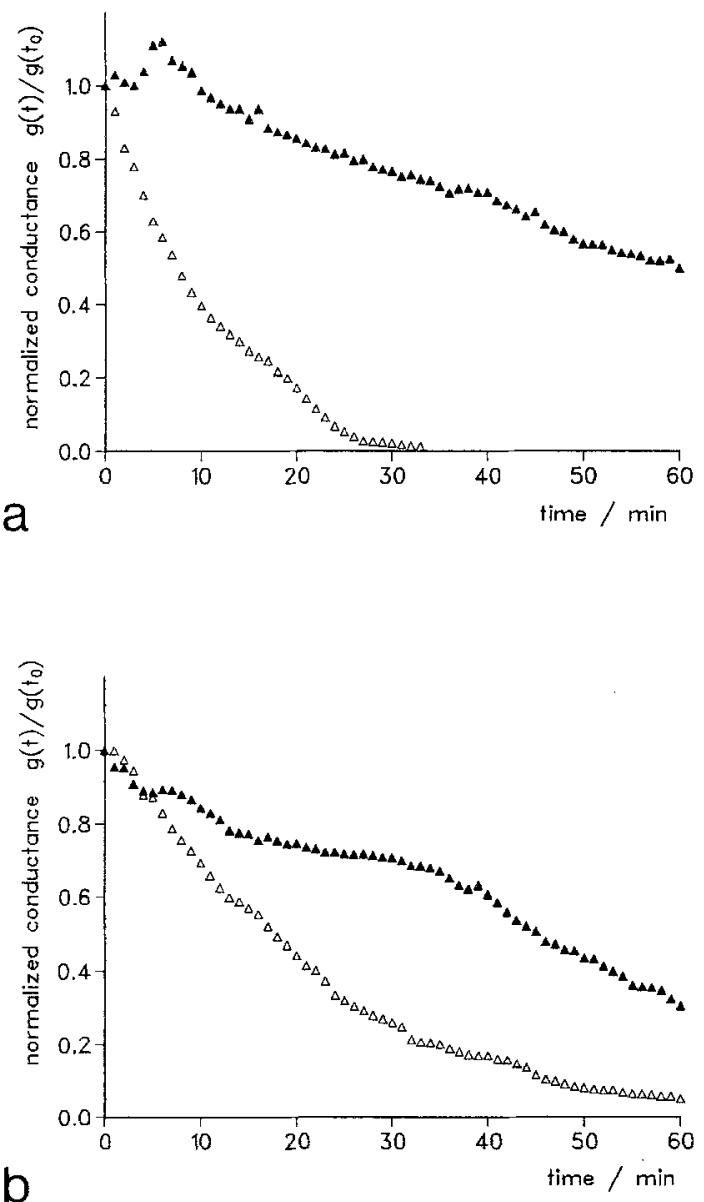

Fig. 6. Time course of junctional uncoupling in (a) BRL and (b) FL cell pairs with normal (intracellular saline, $\triangle$ ) and stabilizing pipette solution (intracellular saline + ATP + dibutyryl-cAMP, $\boldsymbol{\Delta}$ ). Addition of $5 \mathrm{mM}$ ATP and $1 \mathrm{mM}$ dibutyryl-cAMP to the pipette saline markedly reduces the rate of junctional uncoupling

cal uncoupling between cells 1 and 2 was observed. During the uncoupling period, Lucifer yellow was retained in the pipette by a positive holding potential, which was then released and the dye spread into the cells. After 15 min the dye was only present in cells 1 and 3 , indicating a successful blockage of junctional coupling in cell 2,
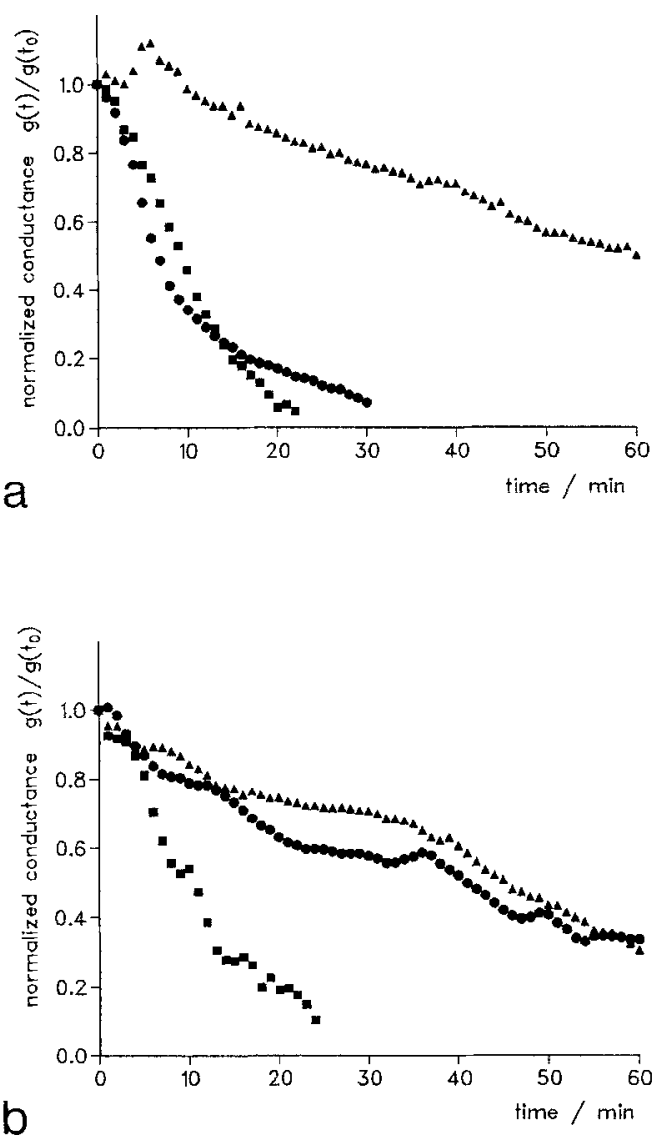

Fig. 7. Time course of junctional uncoupling during antibody perfusion with stabilizing ( IS $_{\mathrm{ATP}}$ ) pipette solution in (a) BRL and (b) FL cell pairs. Control ( IS $_{\text {ATP }}, \boldsymbol{A}$ ), anti-cx26 (ם), anti-cx32 (O). Anti-cx26 blocks junctional conductance in both BRL and FL cells. In FL cells no significant difference in the time course of junctional uncoupling can be seen with anti-cx32 when compared with control measurements. Time constants derived from these measurements are summarized in Table 1

which was dialysed from a patch electrode with antibody. These experiments were carried out for anti-cx32 in both BRL and FL cells. In BRL cells dye spreading was suppressed in nine out of ten, in FL cells in all seven experiments. 


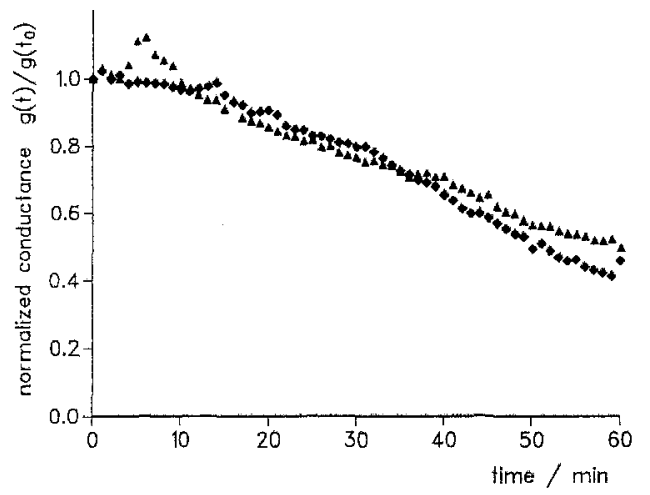

Fig. 8. Time course of junctional uncoupling in BRL cells with preimmune serum in $\operatorname{IS}_{\text {ATP }}(\bullet)$. No difference from control measurements $\left(\mathrm{IS}_{\mathrm{ATP}}, \boldsymbol{\Delta}\right)$, can be seen

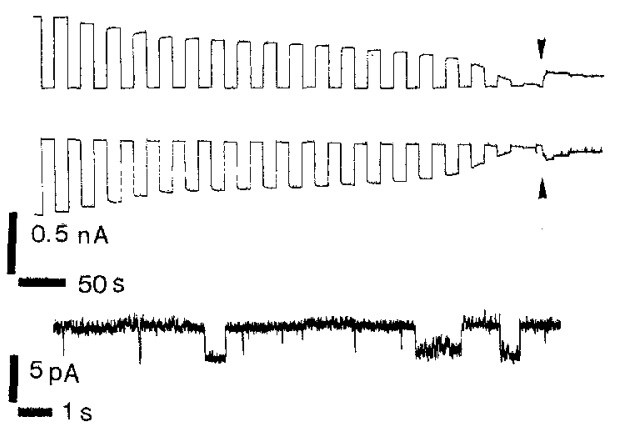

Fig. 9. Single-channel recordings at the end of anti-cx32-antibodymediated uncoupling in BRL cell pairs. Upper two traces: current recordings during junctional uncoupling; arrow indicates gain switching, scale only valid until arrow. Lower trace: high-resolution current recording showing single-channel fluctuations; transcellular voltage was $60 \mathrm{mV}$

\section{Discussion}

In the present experiments the effect of two antibodies directed against connexins $\mathrm{cx} 26$ and $\mathrm{cx} 32$ was investigated on the rate of gap-junctional uncoupling in two cell lines, BRL and FL. Gap-junction channels of both cell lines exhibited a mixed pattern of single-channel conductances with conductance peaks around $60 \mathrm{pS}$ and $90 \mathrm{pS}$, as observed at the end of the spontaneous uncoupling process. Similar observations with different conductance levels were reported for other cell lines (e.g. $[11,13,17,18,21]$ ). Despite their similar conductance levels, we observed, however, that the two antibodies had a different effect in both cell lines. In Buffalo rat liver cells antibodies against the main liver gap-junction proteins, anti-cx 26 and anticx32, blocked gap-junctional conductance; in FL cells, however, only the anti-cx 26 antibody accelerated junctional uncoupling.

This observation raises a number of questions, such as do these antibodies specifically bind to and block connexin channels in viable cells? Which connexin types are present in the cell lines investigated? And which nonspecific effects could be involved? In the ideal case the first question could have been answered if each antibody had eliminated one of the single-channel conduc-

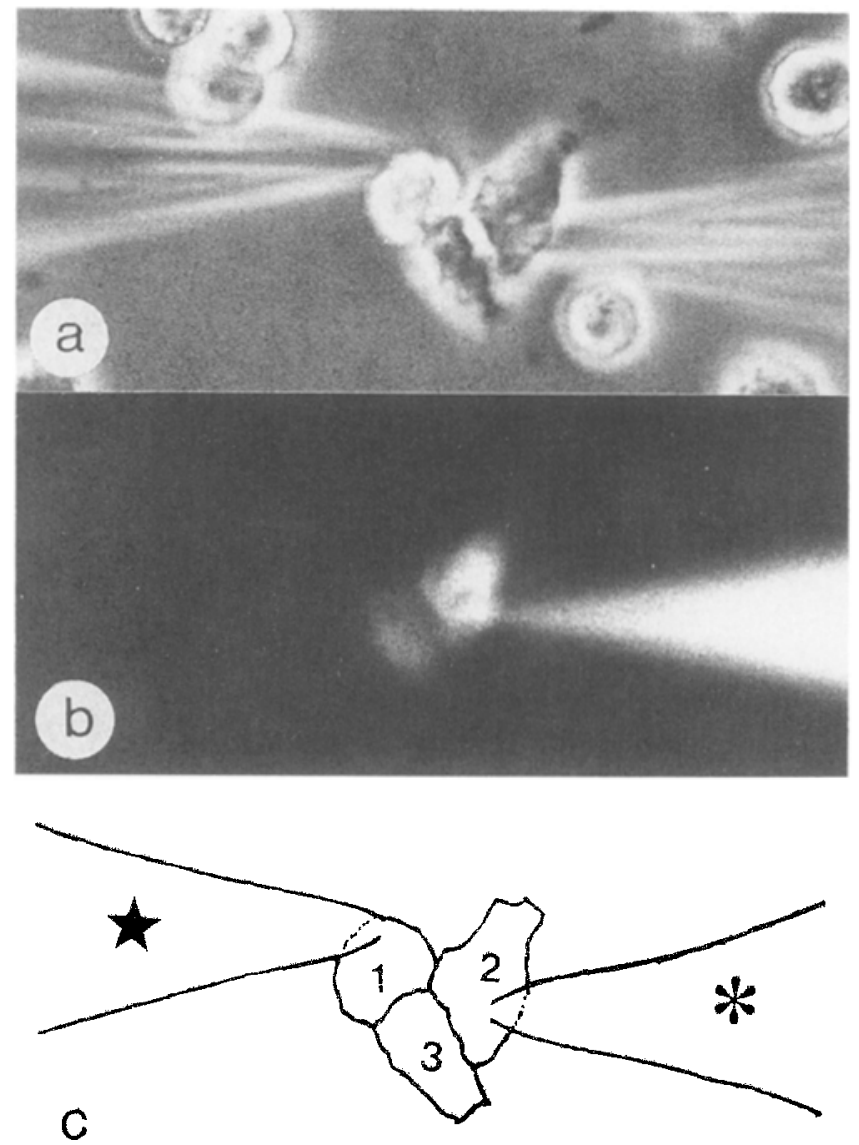

Fig. 10. Anti-cx-32-induced junctional uncoupling in BRL cells, demonstrated by a block of Lucifer yellow spreading: a Phasecontrast image; $\mathbf{b}$ fluorescence image; $\mathbf{c}$ descriptive sketch of the experimental situation. Antibody was perfused into cell 1 from patch pipette $(\star)$ until cells 1 and 2 were electrically uncoupled. Lucifer yellow was then perfused from patch pipette $\left(^{*}\right)$ into cell 2 from where it spread only into cell 3 , which served as an untreated control

tance levels observed so that at the end of an uncoupling experiment only the complementary conductance level prevailed. This, however, was not observed mainly because application of antibody greatly increased the noise level so that single-channel events could no longer be disclosed. A direct correlation between connexin type and channel conductance is, therefore, not possible.

The second question regards the molecular type of the connexin proteins present in BRL and FL cell lines. Unfortunately, this information is not available at present. However, preliminary Western blot experiments from our and from another laboratory (R. Rottler, R. Eckert, and D. F. Hülser, unpublished results; D. Prowse and J. Pitts, personal communication) indicate the presence of cx43 in both BRL and FL cells and do not exclude the presence of a $16-\mathrm{kDa}$ protein in BRL cells. If this finding could be further confirmed, it would suggest that the antibodies were not specific at all but exert some cross-reactivity with the cx43 antigen and/or cytosolic components that interfere with opening or closing of gapjunction channels.

The dye-coupling experiments, on the other hand, offer an alternative interpretation. BRL was the first estab- 
lished cell line where a gap-junction-associated protein of $16 \mathrm{kDa}$ was found [6], and where antibodies against 16-kDa protein from chicken liver caused a functional reaction - the inhibition of dye spreading into or out of a cell injected with this antibody. This was shown independently by Finbow et al. [6] and by Brümmer [3]. In addition in FL cells dye spreading was also blocked by this anti-16-kDa antibody [3]. Since the connexin family and the $16-\mathrm{kDa}$ protein are not homologous in their amino acid sequence [7] cross-reactivity of the respective antibodies does not seem to be likely. Our results may then indicate that several different gap-junction-associated proteins coexist within a functional gap-junction plaque and that in both BRL and FL cells the channels are assembled from a $16-\mathrm{kDa}$ protein, with the connexins acting merely as associated regulatory elements. From the present evidence we are unable to decide whether this alternative has any likelihood.

There is, however, a third possibility. Antibodies have been raised against purified and possibly denaturated proteins and are mainly used for the characterization of gap-junction proteins in immunoblots or for probing of connexin distribution in immunohistochemistry. It is not astonishing, therefore, that antibodies injected into viable cells do not interact with gap-junction channels directly but possibly interfere with other unknown processes that indirectly lead to junctional uncoupling.

In summary we conclude that these antibodies are not specific enough to identify the connexin structure of gapjunction channels during functional studies on gap-junction currents.

Acknowledgements. This work was supported by the DFG (grant $\mathrm{Hu}$ 204/9-4) and by a scholarship to D.P. from Boehringer Ingelheim Fonds. The expert technical assistance of Ms. Beate Rehkopf and Ms. Ulrike Reber is gratefully acknowledged. We thank Drs. O. Traub and $\mathrm{K}$. Willecke (Bonn) for providing us with antibodies, and Dr. M. Finbow (Glasgow) for critical discussion. FL cells were obtained from Dr. K. Redmann (Magdeburg), and BRL cells were obtained from Dr. J. Pitts (Glasgow).

\section{References}

1. Beyer EC, Goodenough DA, Paul DL (1988) The connexins, a family of related gap junction proteins. In: Hertzberg EL, Johnson RG (eds) Gap junctions. Liss, New York, pp 167-175

2. Beyer EC, Paul DL, Goodenough DA (1990) Connexin family of gap junction proteins. J Membr Biol 116:187-194

3. Brümmer F (1987) Farbstoffausbreitung durch Gap Junctions in tierischen Zellkulturen. Stöffler \& Schütz, Stuttgart

4. DeMello WC ed (1990) Cell intercommunication. CRC Press, Boca Raton

5. Eghbali B, Kessler JA, Spray DC (1990) Expression of gap junction channels in communication-incompetent cells after stable transfection with cDNA encoding connexin 32. Proc Natl Acad Sci USA 87:1328-1331

6. Finbow ME, Buultjens TEJ, Serras F, Kam E, John S, Meager $L$ (1988) Immunological and biochemical analysis of the low molecular weight gap junctional proteins. In: Hertzberg EL, Johnson RG (eds) Gap junctions. Liss, New York, pp 53-67
7. Finbow ME, Tompson P, Keen J, Jackson P, Eliopolous E, Meagher L, Findlay JBC (1990) A structural analysis of the gap junction channel and the $16 \mathrm{~K}$ protein. In: Robards AW, Lucas WJ, Pitts JD, Jongsma HJ, Spray DC (eds) Parallels in cell to cell junctions in plants and animals. NATO ASI Series, vol H46. Springer, Berlin Heidelberg New York, pp 15-19

8. Hertzberg EL, Spray DC, Bennett MVL (1985) Reduction of gap junctional conductance by microinjection of antibodies against the $27-\mathrm{kDa}$ liver gap junction polypeptide. Proc Natl Acad Sci USA 82:2412-2416

9. Janssen-Timmen U, Traub O, Dermietzel R, Rabes HM, Willecke K (1986) Reduced number of gap junctions in rat hepatocarcinomas detected by monoclonal antibody. Carcinogenesis 7:1475-1482

10. Kostyuk $P G$, Krishtal OA, Pidoplichko VI (1981) Intracellular perfusion. J Neurosci Methods 4:201-210

11. Neyton J, Trautmann A (1985) Single-channel currents of an intercellular junction. Nature 317:331-335

12. McCann FV, Stibitz GR, Keller TM (1987) A computer method for the acquisition and analysis of patch-clamp single-channel currents. J Neurosci Methods 20:45-55

13. Paschke D (1989) Gap Junction Kanäle mit unterschiedlichen Leitfähigkeiten. Dissertation, Universität Stuttgart

14. Press WH, Flannery BP, Teukolsky SA, Vetterling WT (1989) Numerical recipes in Pascal. Cambridge University Press, Cambridge, UK

15. Pusch M, Neher E (1988) Rates of diffusional exchange between small cells and a measuring patch pipette. Pflügers Arch 411:204-211

16. Robards AW, Lucas WJ, Pitts JD, Jongsma HJ, Spray DC (eds) (1990) Parallels in cell to cell junctions in plants and animals. NATO ASI Series, vol H46. Springer, Berlin Heidelberg New York

17. Rook MB, Jongsma HJ, van Ginneken ACG (1988) Properties of gap junctional channels between isolated neonatal rat heart cells. Am J Physiol 255: $\mathrm{H} 770-\mathrm{H} 782$

18. Rook MB, Jongsma HJ, de Jonge B (1989) Single channel currents of homo- and heterologous gap junctions between cardiac fibroblasts and myocytes. Pfiügers Arch 414:95-98

19. Sachs F (1983) Automated analysis of single-channel records. In: Sakmann B, Neher E (eds) Single-channel recording. Plenum, New York, pp 265-284

20. Sachs F, Auerbach A (1983) Single-channel electrophysiology: use of the patch clamp. Methods Enzymol 103:147-176

21. Somogyi R, Kolb HA (1988) Cell-to-cell channel conductance during loss of gap junctional coupling in pairs of pancreatic acinar and Chinese hamster ovary cells. Pflügers Arch 412:5465

22. Traub O, Look J, Dermietzel R, Brümmer F, Hülser D, Willecke $\mathrm{K}$ (1989) Comparative characterization of the $21-\mathrm{kDa}$ and 26 . $\mathrm{kDa}$ gap junction proteins in murine liver and cultured hepatocytes. J Cell Biol 108:1039-1051

23. Unwin PNT, Zamphigi G (1980) Structure of the junction between communicating cells. Nature 283:545-549

24. Warner AE, Guthrie SC, Gilula NB (1984) Antibodies to gapjunctional protein selectively disrupt junctional communication in the early amphibian embryo. Nature $311: 127-131$

25. Willecke K, Traub O (1990) Molecular biology of mammalian gap junctions. In: DeMello WC (ed) Cell intercommunication. CRC Press, Boca Raton, pp 21-36

26. Zimmer DB, Green CR, Evans WH, Gilula NB (1987) Topological analysis of the major protein in isolated intact rat liver gap junctions and gap junction-derived single membrane structures. J Biol Chem 262:7751-7763 